\title{
Impact of Media on Child
}

\author{
Dr. Pranita Choudhury
}

\section{Introduction:}

Children are universally regarded as the most important asset of any nation. The future of the nation depends directly on how they are brought up and developed. This is why the Universal Declaration of Human Rights adopted way back in 1948 had proclaimed that childhood was entitled to special care and assistance. The United Nations Convention on the Rights of the child adopted in 1989 proclaims in article 6 that every child has the inherent right to life and that the State parties shall ensure to the maximum extent possible for the survival and development of the child. In article 32, the convention mandates the States parties to recognize the rights of the child to be protected from economic exploitation and from performing any work that is likely to be hazardous or to interfere with the child's education or to be harmful to the child's health or physical, mental, spiritual, moral or social development. The United Nations conventions on the Rights of the child, 1989 was the first international treaty to state the full range of civil, political, economic and cultural rights belonging to children. Legally binding on States parties, the Convention details universally recognized norms and standards concerning the protection and promotion of the rights of children - everywhere and at all times. The Convention emphasizes the complementarily and interdependence of children's human rights. The Convention also requires that in all actions concerning children, "the best interests of the child shall be a primary consideration," and that States parties "ensure the child such protection and care as is necessary for his or her well-being" according to Article 3. One of the core principles of the Convention is respect for and consideration of the views of children. The document recognizes in Article 12 children's right to freely express their views in all matters affecting them and insists that these views be given due weight in accordance with the age and maturity of the children. It further proclaims children's right to freedom of all forms of expression as per Article 13. Children are entitled to freedom of thought, conscience and religion according to Article 14. ${ }^{1}$ Each child must have access to information and material from a diversity of national and international sources, especially those aimed at the promotion of his or her social, spiritual and moral well being and physical and mental health.

1. http://www.unicef.org/sowc2012/pdfs/SOWC-2012-The-Convention-on-the-Rights-of-the-Child.pdf

There has been great concern for the welfare of children at the international and national levels. Kofi A. Annan, Secretary General of the United Nations observed that "there is no trust more sacred than the one the world holds with children. There is no duty more important than ensuring that their rights are respected, that their welfare is protected, that their lives are free from fear and want that they grow up in peace". ${ }^{2}$ Mass media must be encouraged to disseminate information and material of social and cultural benefits to the child. These rights need to be balanced with children's right to freedom of expression. This right includes the freedom of expression. Freedom to see, receive and impart information and ideas of all kinds. ${ }^{3}$ The media, especially newspapers, radio and television, are powerful tools in raising awareness to promote children's rights. At many times media focuses on news or stories relating to children. But we need to be aware that the media presents true stories. With an object to make the story interesting, media tends to sensationalise stories, and this might conflict with the child's right to privacy and respect. Publicity may endanger the child's right to safety, protection and development - the child may become a target for violence. There is a particular danger when child survivors of violence or ill- treatment or neglect are photographed or interviewed by the press, radio or television, there is a permanent record that may haunt the child for the rest of his or her life. ${ }^{4}$

The United Nations Convention on the Rights of the Child (UNCRC) sets out what governments and individuals should do to promote and protect the indivisible human rights of all children. The Convention commits governments to ensuring that children can grow up in safe and supportive conditions, with access to high quality education and health care, and a good standard of living. By signing up to the UNCRC, governments agree to protect children from discrimination, sexual and commercial exploitation and violence.

2. Kofi A. Annan in The state of the World's Children (UNICEF, OUP 2000)

3. Sujata Mittal, Children and Media. P.11, Isha books. Delhi.

4. ibid. 


\section{Role Of Media In Protecting Child Right:}

Rising awareness about the rights of children and the promoting of children's right is a challenge to media. Media must not only report fairly, honestly and accurately but they must also provide space for the diverse, colourful and creative opinions of children.

Journalists are champions of human rights. They act as the eyes, ears and voices of the public, drawing attention to abuses of power, human rights and rights relating to children. Through their work they can encourage governments and civil society organisations to effect changes that will improve the quality of children's lives. Journalists and photographers frequently expose the plight of children caught up in circumstances beyond their control, or abused or exploited by adults. The media often depicts children merely as silent 'victims' or charming 'innocents'. By providing children and young people with opportunities to speak for themselves - about their hopes and fears, their achievements, and the impact of adult behaviour on their lives media professionals can remind the public that children deserve to be respected as individual human beings. However, in these circumstances it is equally important to consider or cover up news in a child friendly method. State parties should recognise the right of the child to be protected from economic exploitation and from performing any work that is likely to be hazardous or to interfere with the child's education, or to be harmful to the child's health or physical, mental, spiritual, moral or social development. ${ }^{5}$

Media men should handle news items or stories relating to children very carefully. It is seen that news, media reports, photographs, documentaries and dramas publish news on children exploitation. But at the same time knowingly or unknowingly, media can themselves become the exploiter of children, for instance by creating sexually provocative images of children in news or advertising pornography. Moreover the way media portray children has a profound impact on society's attitude to children and childhood, which also affect the way adults behave.

5. Thomas Paul, Child Labour- Prohibition v. abolition: untangling the constitutional tangle. P.143 Journal of Indian

\section{Law Institute Vol. 50, April-June 2008 No.2.}

Child sex tourism is one area which is exploiting children in the disguise of tourism industry. In many regions particularly South Asia, South East Asia, and some other parts of the world, sexual exploitation of children is an unpleasant by-product of the explosion in tourism. Journalists too are often ignorant of child rights issues and unknowingly or unaware of how media contribute to the commercial process that encourages sexual exploitation of children. ${ }^{6}$ The world Tourism Globe Code of Ethics in article 2 states that individual rights of vulnerable groups of people particularly children should be respected and protected. ${ }^{7}$ Publicity may at the same time endanger the child's right to safety, protection and development- the child may become a target of violence. Sometimes there is a particular danger when child survivors of violence or ill- treatment are highlighted in media.

The Children Act, $1960^{8}$ provides for the care, protection, maintenance, welfare, training, education and rehabilitation of neglected or delinquent children. It also prohibits publication of names of children involved in any proceeding under the Act. No papers, magazines, reports, or newssheets shall disclose the name, address, school or any particulars which leads to identification of the child.

The Press Council of India's norms of journalistic conduct lays the fundamental rule to serve the people with news, views, comments and information on matters of public interest in a fair, accurate, unbiased, sober and decent manner. There is caution against identification. While reporting crime involving rape, abduction or kidnap of women or sexual assault on children or questions touching chastity, personal character and privacy of women. It expects certain norms of professionalism universally recognized and a soft corner for children. Minor children and infants who are the offspring of sexual abuse or forcible marriage, illicit sexual union, photograph of victims shall not be identified or photographed. ${ }^{9}$

6. Sujata Mittal, Children and Media. P.14, Isha books. Delhi.

7. .http://ethics.unwto.org/en/content/global-code-ethics-tourist.

8. The Children Act, 1960 ACT No. LXof 1960

9. Venkat Iyer ed., Mass media laws and regulations in India. $2^{\text {nd }}$ edition (2000) AMIC Nanyang Technological

University, Singapore. P. 543

\section{Children And Media Violence:}

Each child must have access to information and materials from a diversity of national and international sources, especially those aimed at the promotion of his or her social, spiritual and moral well being and physical and mental health. Mass media disseminates information and material of social and cultural benefit of the child. Child rights includes the freedom to see receive and impart information and ideas of all kinds subject to 
restrictions. Children who watch television are not only entertained but assume consciously or unconsciously what they are learning about the world they live in. The media especially newspapers, radio and television, are powerful tools in raising awareness or as partners in an advocacy campaign to promote children's rights. Media offers a lot of entertainment, culture, news, sports and education. They have become important part of our lives and have much to teach our children. But freedom of media at all levels for children does more harm than good. It must be censored and controlled.

Now a days children spend more time with media. Television which once dominated children's media consumption habit, is now joined by computers, video games, cell phones, and other devices. As a result of this, children today are completely immersed in media experiences from a very young age. ${ }^{10}$ Today children are spending an average of seven hours a day on entertainment media, including televisions, computers, phones and other electronic devices. Studies have shown that excessive use of media may lead to problems in children. Compared to previous years children are becoming more violent in their day to day life. They are being self centered. Most researchers of aggression agree that severe aggressive and violent behavior seldom occurs unless there is a convergence of multiple predisposing and precipitating factors such as neurophysiological abnormalities, poor child rearing, socioeconomic deprivation, poor peer relations, attitudes and beliefs supporting aggression, drug and alcohol abuse, frustration and provocation, and other factors. The evidence is already substantial that exposure to media violence is one such long-term predisposing and short term precipitating factor. ${ }^{11}$ Moreover early parenting factors, harsh punishment, rejection of the child, lack of discipline also add to the violent behavior of the child.

10. www.childrennow.org searched on 20.9.2014

11. Sujata Mittal, Children and media. Isha books Delhi. (2005) p.2

Violent shows in TV, films, internet, games have proved harmful to children. The amount of TV and film violence a child is regularly watching is related to child's aggressiveness. There is deep concern all over the world about the too easy access of young people, especially very young children, to programme which contains violence, sex. This is contrary to the Rights of the Child as set out in the UN Convention, which states in Article 3 that in all actions concerning children the best interests of the child shall be a primary consideration. ${ }^{12}$

Media technologies of entertainment and communication are available everywhere. But choosing or selecting media depends on the viewers. If the audiences are young children utmost caution should be taken. Some points about media which seems to be accepted and cautious:

1. Media effects may be benign or malignant. ${ }^{13}$

2. Media collectively operate within a range of other cultural and social factors

3. Media is conditioned by the type of audience- age, gender, sex etc.

4. Media is framed as per norms of the society.

5. Influence is conditioned by the context of reception.

It has been noticed that children are often able to remember messages targeted towards adults also. They remember the content in advertisements aimed at adults. Therefore parents should teach their children how to be critical about media selection and how to become less influenced by the messages in the advertisements. Parents need to teach their children the importance of media and how media play a positive role in their life. Young children learn a lot from the informal sources like television shows, films, internet, social media and other sources and try to imitate a lot of things from them in their life. Such interesting and attractive shows and movies draw or create a permanent picture in their minds. They think that the stories and plays that they see in reels are real and they try to imitate it in their real life. They copy the languages, style, fashion and many other things. It is a duty of the parents and teachers to set limits in the timing to watch these shows. Parents and guardians should at times accompany the child and stop the child from addiction to media.

12. Sujata Mittal, Children and media. Isha books Delhi. (2005) p.9-10

13. Graeme Burton, Media and society, Critical perspectives $2^{\text {nd }}$. Ed. Tata McGraw Hill Education Private

Ltd. P. 100, (2010) N. Delhi.

\section{Advertisement And Children:}

Catch them young is the new advertising mantra. Most of the advertisements especially in television are targeting children. Today they are bombarded with powerful advertising messages from various media which are designed to win their mind and heart. From the time they get up early in the morning till the time they go to sleep they are communicating with thousands of brands through advertisements. They are growing up watching television commercial, listening jingles, playing video games. ${ }^{14}$ Advertisements in the media also affects children. Research has shown that junk food advertisements influence children greatly leading to an increased demand for junk food by children. When children watch young children in good shape or child models eating junk food in the advertisements they assume that it is good for the health. They do not know that junk food is not good for health. They are unaware of the fact that junk food does not contain nutritional value. A 
research conducted has shown that children increased their consumption of junk foods after seeing these advertisements. They are seen to be so influenced by these advertisements that they almost doubled their consumption of these unhealthy snacks and foods. In another study conducted they exposed children to candy commercials. It was seen that those children who were exposed to the candy commercials were highly influenced. In fact, these children chose candy over fruits as snacks. They preferred candy rather than a healthy food like fruits.

Children today enjoy wide access to technology and marketing communications and it is evident that children are increasingly media literate. Due to their vulnerability, inexperience and lack of ability to critically reflect on the received information, advertisers should be especially diligent in protecting these young consumers from harmful, potentially deceptive and offensive information. For example, marketing and advertising to the young generation must not encourage children to be involved in dangerous activities or undermine the authority of their parents. Therefore, it must be regulated in terms of both the language and images they use and all the topics that might potentially cause negative effects on children must be excluded from both the programmes and the advertisements that might be watched by children. ${ }^{15}$

14. http://ciet.nic.in/MediaClub/pdf/advertising_and_impacts.pdf

15.http://www.iccwbo.org/Advocacy-Codes-and-Rules/Areas-of-work/Marketing-and-Advertising/

\section{Implications Of New Technologies:}

Computers are exceptionally powerful cognitive tools. It is a new 'paradigm shift'. It has become important to reflect on the effects of developing technologies on young audiences. It has changed what children do with their leisure time. They have more access to more materials and more communication devices than their parents ever had. ${ }^{16}$

Now a days children have personal computers, TV in their bedrooms, easy access to new technologies like You Tube, Face Book, Twitter, YouTube etc. These rapid changes are seen with the technological revolution. New means of communication have developed with the aid of internet and satellite based communication. Social Media refers to means of interaction or communication among people. It is the fastest means of communication to pass on massages. Social media communication has become very popular among young children. They can communicate with their friends far and wide very easily. These open up a lot of informal learning in children. But at the same time they also feature some unwanted and unaccepted information and pictures which should not be open to children.

Media psychology seeks to understand how media as a factor in the growing use of technology impacts young people to perceive, interpret, respond, and interact in a media rich world. Media psychologists typically focus on identifying potential benefits and negative consequences of all forms of technology and work to promote and develop positive media use and applications. Children are not just passive consumers of media, but active members because they have up to date information relating to shows in the media. Parents and guardians should help the children to criticize and judge and advice them not to consume each and everything shown by media. Restrictions and regulations are necessary

The song and drama units utilize live entertainment media to make the masses aware of the various national programmes and objectives. It has a wide range of stage forms like puppet shows, plays, dances, dramas, ballads, harikathas and sound and light shows. ${ }^{17}$

\section{Graeme Burton, Media and society, Critical perspectives $2^{\text {nd }}$. Ed. Tata McGraw Hill Education Private}

Ltd. P.127, (2010) N. Delhi.

17. RK Ravindran. Handbook of mass media, Anmol publications pvt. Ltd.N.Delhi.(1999) P.135

\section{Constitution Of India And Child Rights:}

Our constitution makers, wise and sagacious as they were, had known that the India of their vision would not be a reality if the children of the country are not nurtured and educated. ${ }^{18}$ Children are the most vulnerable sections of society. They become victims of exploitation and ill-treatment easily and can be directed into undesirable channels by anti-social elements. The Indian Constitution guarantees all children certain rights, which have been specially included for them.

Some important Articles specially frames for the development and protection of children are:

\section{Article 14 - Right to equality.}

Article 15(4) - provides that the state shall not prevent from making any special provision for women and children. This is in reference to extra protection given to children.

Article 21- Segregation of children and women prisoners. No procedure can be said to be fair and reasonable which allows women or children or children to be locked up with other prisoners. In Sheela Barsey 
vs. Union of India, ${ }^{19}$ the Supreme Court emphasized that children should not be confined to jail because incarceration in jail has a dehumanizing effect and is harmful to the growth and development of children. It would also result in mental torture and may haunt them for the rest of their life.

Article 24- Right to be protected from any hazardous employment till the age of 14 years. Although, Article 24 states that no child below 14 years shall work in mines, factories and other hazardous occupation, Chandrachud, former Chief Justice of India states, " this does not give the legislature a charter to put children to work in other occupations. Article 24 has to be studied in a particular context and it is the interpretation of this article in the light of the directive principles of state policy which is crucial." ${ }^{20}$

18. Mamta Rao, Law relating to women and children. $3^{\text {rd }}$.ed. Eastern book co. Lucknow(2012) p.554

19. Sheela Barsey vs. Union of India. 19953 SCC 743.

20. Journal of the Indian Law Institute, Vol.50 No. 2. April- June 2008, p.169

The factual position of child labour in spite of the constitutional provisions is very grim. The problem of child labour in India is acute, severe and multidimensional. Illiteracy, ignorance and neglect of media are some of the reasons. Children in the carpet industry are reported to be branded with red hot iron rods, burnt with cigarette butts and hanged upside down for minor faults. ${ }^{21}$

Article 39(e) - State shall direct its policy towards securing the health and strength of workers, men and women; and that children of tender age will not be abused; that citizens should not be forced by economic necessity to enter into avocations unsuited to their age and strength.

Article 39 (f) enjoins that the State shall direct its policy towards securing that children are given opportunity and facilities to develop in a healthy manner and in conditions of freedom and dignity; and that children and youth are protected against exploitation and moral and material abandonment.

Article 45- mandates that the State shall endeavour to provide free and compulsory education for all children until they complete the age of 14 . exploitation

Article 46- Right of weaker sections of the people to be protected from social injustice and all forms of public health.

Article 47- Raise the level of nutrition and standard of living of its people and the improvement of

Article 51A- provides fundamental duties that citizens shall act in such a manner that the nation constantly rises to higher levels of endeavour and achievement.

Thus the constitution mandates that every child shall have the right to health, well-being, education and social protection without any discrimination on the ground of caste, birth, colour, sex, language, religion, social origin, property or birth. In India child labour is discouraged. But there is no outright ban on child labor, and the practice is generally permitted in most industries except those deemed "hazardous". Little is being done to address the problem since the economy is booming and the nuclear family is spreading, thereby increasing demand for child labourers. Many children are still mal-nutrition and abandoned in the road side.

21. Mamta Rao, Law relating to women and children. $3^{\text {rd }}$.ed. Eastern book co. Lucknow(2012) p.554

\section{Conclusion}

Media has great impact on children. Rising awareness about the rights of children, the promotion and development of children's right is a challenge to media. It is the duty of the media not only to report fairly, honestly and accurately but they must also provide space for the diverse, colourful and creative opinions of children. They create awareness about their rights and acknowledge the children that such rights are not favours, but they are human rights which should be available to each child regardless of any type of differences. It is the media to inform ways to achieve and claim those rights. Media is to enlighten to the public about the allotment of funds assigned for development of children. Right to life, education, nutritious food, good health, shelter, protection and all round development of the children are features to be highlighted by the media.

But today we see a different picture altogether. The media is not playing the role of the fourth estate. It is rather playing the role of commercial agent or advertiser. They are becoming more pervasive, more intrusive, and more disturbing in content. They are popular in advertising commercial products of companies who can pay them. They are sponsored by companies in all shows. Even children shows are becoming commercial and they are hardly concerned about the issues or rights of children. They are least bothered about the under privileged or sufferings of the huge number of children who are helpless.

Media has now created a very alarming situation. Social media, television and films seems to be an especially threatening because it brings into our homes, automatically, so many things which most parents would never choose to expose their children to. Parents are at a loss as to what to do to protect their children. Children today hardly go for books or games but they easily choose a remote to view the channels or games which is readily available at the touch of a remote almost any time of the day or night. 
Media is the best informer to a child. Through their stories or games lessons can be thought to children. They should pass good message in interesting ways. Media should give moral thoughts, good lessons, love for ones motherland, respect and love towards man and environment. The best interests of children must be the primary concern of mass media. 